\title{
Analisa Teknis dan Ekonomis Pengembangan Industri Personal Watercraft
}

\author{
Rizal Mataram Matovani, Triwilaswandio Wuruk Pribadi \\ Departemen Teknik Perkapalan, Fakultas Teknologi Kelautan, Institut Teknologi Sepuluh Nopember (ITS) \\ e-mail: triwilas_its@perkapalan.its.ac.id
}

\begin{abstract}
Abstrak-Personal Watercraft atau yang lebih dikenal dengan sebutan Jet Ski telah menjadi suatu wahana olahraga laut yang digemari di Indonesia karena kecepatan dan manuver-abilitynya yang sangat baik. Belum adanya industri personal watercraft di Indonesia menjadi peluang tersendiri untuk dibangun industri sejenis guna memenuhi lonjakan tren permintaan produk personal watercraft sebagai wahana rekreasi maupun kegunaan lainya. Tujuan dari studi ini adalah untuk menghitung kebutuhan, analisis teknis dan ekonomis dari industri personal watercraft di Indonesia. Penelitian ini diawali dengan melakukan forecasting terhadap permintaan produk personal watercraft, kemudian prospek penggunaan personal watercraft, serta analisis teknis dan ekonomis personal watercraft. Pemilihan dan perhitungan kontruksi material fiberglass sebagai material utama bagian lambung dan bangunan atas personal watercraft telah melalui perhitungan berdasarkan pada peraturan kelas ABS untuk kapal cepat. Proses laminasi fiberglass yang di gunakan adalah metode vacuum infusion dikarenakan investasi yang dibutuhkan lebih kecil dibandingkan dengan metode compression moulding. Berdasarkan analisis yang telah dilakukan. Industri ini membutuhkan tanah seluas $1.584 \mathrm{~m}^{2}$, dengan luas bangunan tertutup sebesar $844,5 \mathrm{~m}^{2}$. Biaya investasi yang dibutuhkan sebesar Rp. 10,058 milliar payback period terjadi pada tahun ke 9 bulan ke 8 dengan nilai net present value sebesar Rp. 1,136 milliar, dan IRR sebesar $12,02 \%$ lebih besar dari suku bunga investasi yakni $11 \%$, sehingga investasi ini dapat dikatakan layak.
\end{abstract}

Kata Kunci-Industri Personal Watercraft, Material Fiberglass, PWC, Vacuum Infusion.

\section{PENDAHULUAN}

I NDONESIA sebagai salah satu negara maritim terbesar di dunia, dimana 2/3 wilayah Indonesia merupakan lautan yang kaya akan sumber daya alamnya utamanya pada bidang kepariwisataan baharinya. Di beberapa daerah dengan perairan laut yang tenang, telah ditemukan banyak bisnis di bidang rekreasi maritim yaitu olahraga laut atau biasa disebut water sport juga berbagai wahana pengembangan hobi dan olahraga yang berhubungan dengan sarana transportasi laut. Perkembangan tersebut memunculkan demand akan adanya suatu industri penunjang aktivitas-aktivitas rekreasi air dalam hal ini yang berupa produk-produk kecil, cepat dan mudah digunakan yaitu personal watercraft (PWC).

PWC banyak digunakan dalam berbagai rekreasi dan olahraga air baik di laut, sungai, maupun danau. Penggunaanya yang mudah dan harganya yang terbilang lebih murah dibandingkan kapal-kapal rekreasi yang lebih besar lainya menjadi faktor penting pendongkrak popularitas dari produk
PWC. Di indonesia PWC lebih dikenal dengan sebutan Jet Ski yang sebenarnya adalah merupakan merk dagang dari Kawasaki. Meski sudah cukup populer di Indonesia namun produk PWC sebenarnya masih merupakan produk impor yang tidak terdapat industri nya di indonesia, sehingga menyebabkan harga per-produknya melonjak tinggi dikarenakan pajak barang mewah, bea cukai dan pajak penerimaan negara lainya.

Ketiadaan Industri personal watercraft ini tentunya menjadi peluang usaha yang sangat menjanjikan bagi para investor mengingat semakin banyaknya permintaan produk PWC yang lebih terjangkau dengan kualitas yang baik dalam memenuhi kebutuhan pasar di Indonesia. Oleh karena itu penulis mengambil topik mengenai pengembangan industri personal watercraft. Melihat adanya potensi besar dalam perkembangan bisnis olahraga laut yang berimbas pada industri produk personal watercraft, penulis mencoba menganalisa faktorfaktor penghambat kemajuan industri personal watercraft dan merumuskan strategi pengembangan yang tepat sesuai permasalahan yang dihadapi serta menganalisa secara teknis dan ekonomis terhadap produk personal watercraft.

Dengan adanya industri personal watercraft di Indonesia, diharapkan mampu termasyarakatkanya produk personal watercraft buatan dalam negeri agar bisa bersaing dengan industri personal watercraft luar negeri. Karena besarnya peluang ini, maka perlu diadakan penelitian studi tentang Analisa Teknis dan Ekonomis Pengembangan Industri Personal Watercraft.

\section{STUDI LITERATUR}

\section{A. Personal Watercraft}

Kata Jetski yang sering kita dengar sebenarnya adalah brand personal watercraft dari merk kawasaki yang mana Istilah ini sering digunakan secara umum untuk merujuk pada jenis personal watercraft lainya. Personal watercraft juga disebut skuter air, adalah perahu rekreasi dimana pengendara duduk atau berdiri di atas, bukan di dalam, seperti dalam perahu. Memiliki mesin sistem jet pump yang memiliki sekrup berbentuk impeller untuk menciptakan daya dorong untuk propulsi dan kemudi. Beberapa Merk Dagang Terkenal adalah Jet Ski, Wave Runner, atau Sea-Doo. Kebanyakan dirancang untuk dua atau tiga orang, meskipun model empat penumpang juga ada. personal watercraft memang menyenangkan tetapi bermain PWC sebenarnya membutuhkan konsentrasi tinggi. 
Inti dari mengendarai PWC adalah sang pengendara harus mampu menjaga keseimbangan saat melakukan atraksi di air. Intinya memang perlu pengetahuan akan teknik yang tepat untuk melakukan permainan menantang ini. Selain membutuhkan ombak dalam permainan personal watercraft, olah raga air ini juga dikenal dengan olah raga mahal. Sehingga memang "cocok" bagi orang berkantong tebal.

B. Metode Vacuum Infusion Process (VIP) untuk Laminasi Pembangunan Personal Watercraft FRP

Metode vacuum infusion process (VIP) masih termasuk dalam kategori closed molding method sama seperti compression molding. Namun VIP memiliki keunggulan terutama dalam hal investasi awal dimana peralatan penunjang yang digunakan lebih murah namun membutuhkan waktu curing/solidification yang lebih lama ketimbang compression molding process. Lain halnya dengan compression molding yang menggunakan SMC sebagai material seratnya, VIP menggunakan lembaran serat yang lebih fleksibel dan sama seperti pada metode hand lay up. Meskipun menggunakan material yang sama VIP memiliki keunggulan dalam hal kekuatan dibandingkan dengan metode hand lay up dikarenakan teknik vacuum udara yang meningkatkan kompresi serta penyebaran resin yang lebih merata dimana produk dengan kekuatan yang sama dapat dicapai dengan ketebalan yang lebih tipis. Vacuum infusion process dipilih karena lebih memungkinkan pembuatan part/komponen dari produk dengan ukuran yang lebih besar namun biaya investasi yang lebih murah dibanding compression molding [1]. Berikut beberapa perbandingan VIP dan compression molding.

Tabel 1

Perbandingan VIP dan Compresion Molding

\begin{tabular}{|l|l|l|}
\hline \multicolumn{3}{c}{ Perbandingan VIP dan Compresion Molding } \\
\hline KATEGORI & Vaccum Infusion Process & Compression Molding \\
\hline Volume Produksi & $<500$ (unit) & $10.000-75.000$ (Unit) \\
\hline Siklus Proses Laminasi & $4-8$ jam & $2-6$ Menit \\
\hline Kerumitan Struktur & Baik & Sangat Baik \\
\hline Biaya Investasi & Tinggi & Sangat tinggi \\
\hline Dampak Lingkungan & Rendah & Rendah \\
\hline
\end{tabular}

Tabel 1 menunjukkan perbandingan antara vacuum infusion molding dan compression molding dimana perbandingan mengulas beberapa aspek seperti volume produksi, siklus proses, kerumitan struktur produksi, biaya investasi dan dampak lingkungan.

\section{C.Standar Klasifikasi ABS Mengenai Pembangunan High Speed Craft FRP}

Untuk menentukan kebutuhan laminasi maka diperlukan perhitungan luasan bagian dari PWC yang perlu di laminasi. Hal ini diselesaikan dengan melakukan pengggambaran linesplan bentuk produk PWC.

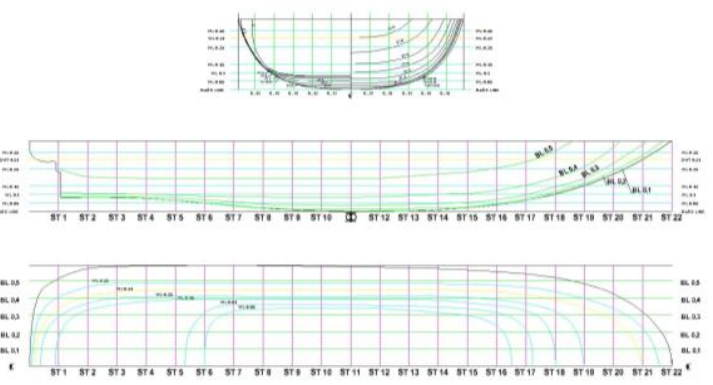

Gambar 1. Linesplan Personal Watercraft

Perhitungan ketebalan dan Design Pressure dari kulit personal watercraft menggunakan rumus dari American Bureau of Shipping Guide for Building and Classing HighSpeed Craft. Perhitungan design pressure dapat ditemukan pada part 3 section 8 dan perhitungan ketebalan pelat laminasi FRP pada part 3 Section 9 [2].

a. Bottom slamming pressure for monohull craft

$$
p_{b x x}=\frac{N_{1} \Delta}{L_{w} B_{w}}\left[1+n_{c g}\right] F_{D} F_{v} \quad \mathrm{kN} / \mathrm{m}^{2}
$$

b. Hydrostatic Pressure

$$
p_{d}=N_{3}\left(F_{s} H+d\right) \mathrm{kN} / \mathrm{m}^{2}
$$

Berikut adalah rumus perhitungan ketebalan laminasi FRP: a. All plating

$$
t=s c \sqrt[3]{\frac{p k_{1}}{1000 k_{2} E_{F}}} \mathrm{~mm}
$$

\section{METODOLOGI PENELITIAN}

\section{A. Teknik Pengumpulan Data}

Pada tahap ini akan dilakukan pengumpulan data yang dilakukan dengan cara seperti di bawah ini :

\section{a. Studi Pustaka}

Studi pustaka dilakukan dengan mempelajari referensireferensi yang berkaitan dengan permasalahan yang sedang dibahas untuk memperoleh konsep dan teori dasar mengenai ekonomi teknik serta kondisi industri manufaktur bangunan lepas pantai.

\section{b. Survey Pendahuluan}

Survey pendahuluan dilakukan untuk memperoleh gambaran awal dari permasalahan yang dibahas oleh peneliti. Survey pendahuluan meliputi survey tentang bisnis dan peluang dari industri manufaktur bangunan lepas pantai.

\section{c. Survey Lapangan}

Survey lapangan dilakukan dengan mengamati langsung objek yang akan diteliti sehingga akan diperoleh data-data yang dapat membantu penyelesaian studi ini.

\section{B. Analisa Data}

Analisa yang diperlukan dalam penyelesaian studi ini adalah menggunakan analisa teknis dan ekonomis. Analisa teknis 
yang dilakukan meliputi pemilihan lokasi pembangunan industri manufaktur bangunan lepas pantai, penentuan jumlah kebutuhan fasilitas produksi, perencanaan jumlah tenaga kerja yang dibutuhkan baik tenaga kerja langsung maupun tenaga kerja tak langsung, perencanaan struktur organisasi perusahaan sera perencanaan luas area dan desain layout industri yang sesuai. Sedangkan analisa ekonomis yang dilakukan yaitu menentukan besarnya nilai investasi yang diperlukan dalam pembangunan industri manufaktur bangunan lepas pantai yang terdiri dari biaya persiapan dan manajemen, biaya pembebasan lahan, biaya pembuatan bangunan dan biaya pengadaan fasilitas produksi. Selain itu dilakukan analisa mengenai pengeluaran yang dilakukan oleh perusahaan yang terdiri dari biaya bahan baku, biaya tenaga kerja, dan biaya operasional lain, sehingga dapat diketahui besarnya pendapatan yang didapatkan perusahaan. Kemudian dilakukan analisa mengenai waktu kembali dari investasi yang telah dilakukan serta mengenalisa kelayakan pembangunan industri manufaktur bangunan lepas pantai.

\section{KONDISI EKSISTING DAN ANALISA MARKET}

\section{A. Kondisi Eksisting Industri Personal Watercraft}

Berdasarkan hasil pengamatan langsung dan pencarian data dari penulis, diketahui bahwa industri Personal Watercraft di Indonesia masih belum ada. Produk- produk Personal Watercraft merupakan barang import yang masuk dari berbagai negara dan memiliki harga yang cukup tinggi karena pajak dan biaya lainya. Produk ini masih menjadi produk yang sulit dimiliki kalangan pribadi kecuali kalangan tertentu karena di golongkan dalam kategori barang mewah. Tentunya produk ini akan sangat berpotensi dalam berbagai bidang tidak hanya rekreasi bila produk didapat dengan mudah dan lebih murah, tidak dapat dipungkiri produk ini menjadi salah satu yang diusulkan sebagai cabang olahraga yang dipertandingkan dalam Asian Games 2018 dikarenakan kemenangan atlet Indonesia sebelumnya.

\section{B. Potensi Pasar}

Dalam perencanaan pembuatan industri personal watercraft, maka diperlukan konsumen yang akan membeli produk tersebut sehingga dapat memberikan pemasukan bagi perusahaan. Dari data konsumen dapat diketahui besarnya kesempatan membangun industri ini di Indonesia. Berikut ini adalah beberapa konsumen atau market potensial dari industri personal watercraft:

1. PT.Zooka Dive and Water Sport

2. PT. Tanjung Benoa Water Sport

3. BMR Dive and Water Sport

4. PT.Apollo Dive and Water Sport

5. Basuka Watersport

6. Pandawa Water Sport Bali

7. PT. Mekarsari

8. PT.Apollo Dive and Water Sport

9. Badan Penyelamat Wisata Tirta (BALAWISTA)

10. Polisi Perairan Republik Indonesia

11. Sea Doo Club Indonesia

\section{Marina Club}

13. dll

Perusahahan-perusahaan di atas merupakan perusahaan calon konsumen industri personal watercraft, Kebanyakan merupakan perusahaan penyedia wisata wahana olahraga laut namun terdapat pula instansi resmi seperti POLAIR dan organisasi penyelamat pantai serta kalangan pribadi maupun organisasi pecinta PWC. Masih banyak lagi perusahaan serupa yang juga masih potensial mengingat berdasarkan analisa awal harga produk nantiya akan jauh lebih murah dibandingkan dengan produk import.

\section{Pengolahan Data}

Dalam pengolahan data ini dilakukan beberapa proses, yaitu peramalan dan perencanaan produk. Untuk peramalan dilakukan pengolahan data pembangunan PWC dari tahun 2012-2016. Dari hasil peramalan tersebut akan menjadi acuan dari kondisi pasar untuk lima tahun yang akan datang. Berikut adalah penjelasan mengenai proyeksi pembangunan produk personal watercraft:

Untuk proyeksi permintaan PWC yang diteliti, di lakukan peramalan permintaan yang diperoleh dari data penjualan PWC 5 tahun belakangan. Data acuan adalah data yang diperoleh dari PT.KBA Yamaha selaku distributor produk WaveRunner di Indonesia [3]. Personal watercraft dalam data yang digunakan untuk peramalan tidak memerdulikan jenis maupun desain serta kapasitas PWC, kesemuanya dianggap sama. Untuk detail perhitunganya dapat dilihat pada Lampiran A. Pehitungan Forecasting.

Tabel 2

Data rata-rata jumlah penjualan PWC

\begin{tabular}{|l|c|c|c|c|c|c|c|}
\hline Data Penjualan PWC & $\mathbf{2 0 1 2}$ & $\mathbf{2 0 1 3}$ & $\mathbf{2 0 1 4}$ & $\mathbf{2 0 1 5}$ & $\mathbf{2 0 1 6}$ & Jumlah & Rata-Rata \\
\hline PT.KBA Yamaha & 79 & 87 & 96 & 90 & 88 & 440 & 88 \\
\hline
\end{tabular}

Tabel 2 menjelaskan tentang jumlah permintaan PWC dalam kurun waktu 5 tahun ke belakang yang di dapat dari PT.KBA Yamaha. Langkah selanjutnya adalah pembuatan grafik untuk mengetahui pola permintaan sehingga dapat mempermudah penentuan metode forecasting yang tepat. Berikut adalah grafik data permintaan PWC pada tahun 20122016.

Tabel 3

Data hasil peramalan jumlah penjualan PWC

\begin{tabular}{|l|r|r|r|r|r|}
\hline Hałkil Peramalan PWC & \multicolumn{1}{|c|}{2017} & \multicolumn{1}{|c|}{2018} & \multicolumn{1}{c|}{2019} & \multicolumn{1}{c|}{2020} & \multicolumn{1}{c|}{2021} \\
\hline Jumlah Permintaan & 91 & 90 & 90 & 90 & 90 \\
\hline
\end{tabular}

Tabel 3 merupakan hasil peramalan permintaan PWC untuk tahun 2017-2021. Dari hasil peramalan tersebut, jumlah permintaan terbanyak terjadi pada tahun 2017 dengan 91 unit. Sedangkan 2018-2021 menjadi tahun paling sedikit dengan 90 unit. Untuk mengetahui performa peramalan maka dilakukan perhitungan koreksi dengan menggunakan mean square error (MSE). Berikut contoh hasil perhitungan MSE dari salah satu metode moving average produk PWC [4]. 


\section{ANALISA TEKNIS INDUSTRI PERSONAL WATERCRAFT}

\section{A. Desain Produk}

Produk yang direncanakan akan dibangun oleh industri personal watercraft nantinya adalah menyerupai produk yang sudah ada sebelumnya. Pada produk ini mengkhususkan penggunaanya untuk tujuan rekreasi yang bisa digunakan oleh anggota keluarga dengan kursi penumpang yang berkapasitas 3 orang.

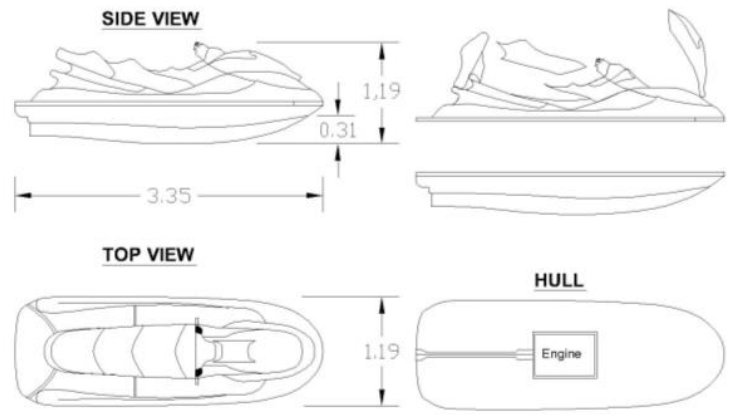

Gambar 2. Design Produk Personal Watercraft yang akan Diproduksi.

Gambar 2 adalah desain $P W C$ yang didesain lebih nyaman dan ditujukan untuk rekreasi dengan kapasitas 3 orang (keluarga) untuk semua kalangan. Berikut adalah spesifikasinya:

$\begin{array}{ll}\text { Length }(\mathrm{m}) & 3.35 \\ \text { Width }(\mathrm{In} / \mathrm{Mm}) & 48 / 1219.2 \\ \text { Height }(\mathrm{In} / \mathrm{Mm}) & 47 / 1193.8 \\ \text { Draft }(\mathrm{m}) & 0.3059 \\ \text { Dry Weight }(\mathrm{Lbs} / \mathrm{Kg}) & 769 / 348.8 \\ \text { Payload Capacity }(\mathrm{Lbs} / \mathrm{Kgs}) & 353 / 160 \\ \text { Fuel Capacity }(\mathrm{Gal} / \mathrm{L}) & 18.5 / 70 \\ \text { Top Speed }(\mathrm{kn}) & 40\end{array}$

\section{B. Proses Produksi PWC}

Produk personal watercraft adalah produk massal yang di produksi dengan metode vacuum infusion process (VIP). Pada proses pembuatan produk PWC dibutuhkan beberapa tahap. Dimulai dari proses Persiapan dan laminasi (persiapan cetakan dan material, pemotongan, laminasi) dilanjutkan dengan Assembly (Installasi Kabel, permesinan, instalasi komponen electrical, penggabungan hull/deck), Finishing (Pemasangan perlengkapan dan Pemberian dekorasi tampilan), pengujian (visual check, function test, internal shop test) dan delivery (packing dan pengiriman). Berikut adalah alur proses pembuatan PWC terdapat pada diagram berikut

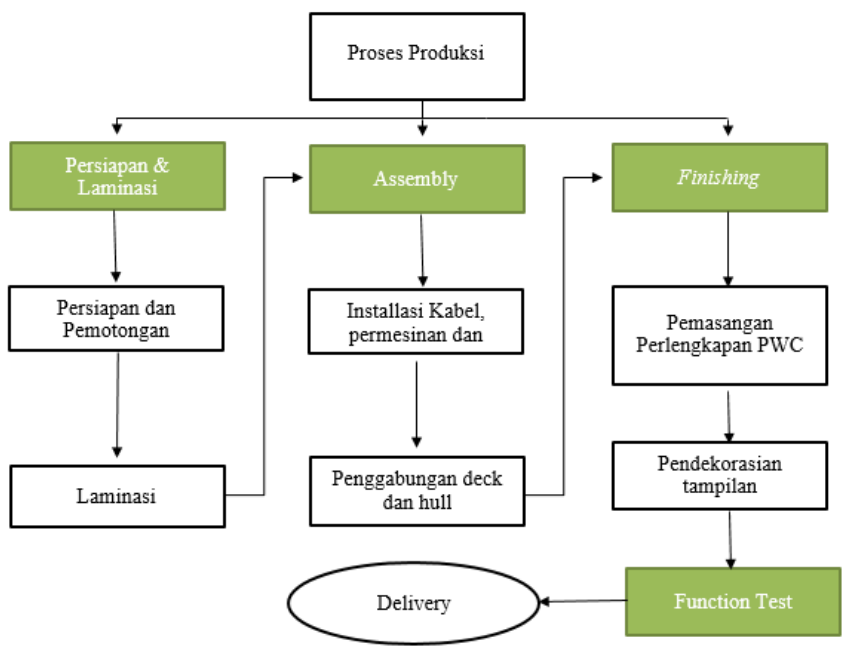

Gambar 3. Diagram proses produksi personal watercraft.

Gambar 3 adalah alur proses pembuatan PWC dengan material fiberglass. Proses berawal Tahap laminasi sampai pada delivery.

\section{Layout Industri Personal Watercraft}

Desain layout office industri personal watercraft dapat direncanakan dan dikembangkan seperti pada gambar di bawah ini.

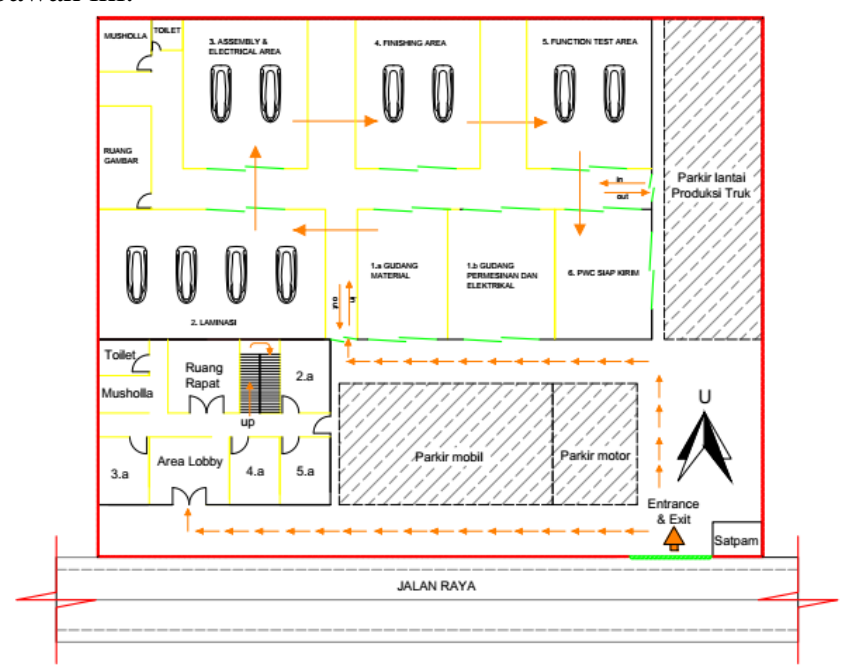

Gambar 4. Layout Industri Personal Watercraft

Gambar 4 menunjukkan total luas tanah yang diperlukan untuk membangun perusahaan personal watercraft adalah $1.584 \mathrm{~m}^{2}$. Total luas bangunan yang dibutuhkan untuk industri personal watercraft adalah $844,5 \mathrm{~m} 2$ dengan office pada lantai 1 dan 2 .

\section{ANALISA EKONOMIS}

\section{Analisis Penentuan Biaya Industri Personal Watercraft}

Biaya investasi untuk mendirikan industri personal watercraft. Hal tersebut dilakukan untuk mengetahui besarnya biaya investasi pembangunan industri PWC juga berapa lama pengembalian modal akan tercapai. Untuk perhitungan lebih 
detail dapat dilihat pada Lampiran C. Perhitungan Analisis Kelayakan Investasi.

Tabel 4.

Total Biaya Investasi Industri Personal Watercraft

\begin{tabular}{|c|c|c|c|c|c|c|}
\hline No. & Nama Alat & Ukuran (m2) & Jumlah & Harga $(\mathrm{Rp})$ & & Total \\
\hline 1 & Tanah di Sidoarjo & $1.584,00$ & 1 & 4.000 .000 & $\mathrm{Rp}$ & 6.336 .000 .000 \\
\hline 2 & Biyya Pembangunan Kantor dan Workshop & & & & $\mathrm{Rp}$ & 1.386 .811 .719 \\
\hline 3 & Biaya Instalasi listrik, air dan tepon & 84,50 & 1 & $\begin{array}{ll}\mathrm{Rp} & 100.000 \\
\end{array}$ & $\mathrm{Rp}$ & 84.450 .000 \\
\hline 5 & Personal computer desain dan kantor & & 15 & $\begin{array}{ll}\text { Rp } & 11.139 .000 \\
\end{array}$ & $\mathrm{Rp}$ & 167.085 .000 \\
\hline 6 & Fooklifit 1 Ton & & 2 & Rp $\quad 175.000 .000$ & Rp & 350.000 .000 \\
\hline 7 & Boat Trailer & & 1 & $\begin{array}{ll}\text { Rp } \quad 105.300 .000 \\
\end{array}$ & $\mathrm{Rp}$ & 105.300 .000 \\
\hline 8 & Overhead Crane 1 Ton & & 2 & $\begin{array}{ll}\mathrm{Rp} & 68.000 .000 \\
\end{array}$ & $\mathrm{Rp}$ & 136.000 .000 \\
\hline 9 & Kendaraan Operasional & & 2 & $\begin{array}{ll}\text { Rp } \quad 185.000 .000 \\
\end{array}$ & $\mathrm{Rp}$ & 370.000 .000 \\
\hline 10 & Peralatan Pemadam Kebakaran 15L & & 6 & \begin{tabular}{|ll}
$\mathrm{Rp}$ & 2.825 .000 \\
\end{tabular} & $\mathrm{Rp}$ & 16.950 .000 \\
\hline 11 & Biaya Peralatan produksi & & & & $\mathrm{Rp}$ & 22728.000 \\
\hline 12 & Generator Set 30KVA & & 1 & $\begin{array}{ll}\mathrm{Rp} & 65.000 .000 \\
\end{array}$ & & 65.000 .000 \\
\hline 13 & Biaya Persiapan dan Intalasi & & & & $\mathrm{Ro}$ & 1.017 .770 .000 \\
\hline & & & & & $\mathbf{R p}$ & 10.058 .094 .719 \\
\hline
\end{tabular}

Tabel 4 menunjukkan total investasi pembangunan industri personal watercraft. Berdasarkan data di atas, maka total investasinya sebesar Rp 10.058.094.719.

\section{E. Analisis Biaya Operasional}

Biaya-biaya operasional yang akan dikeluarkan saat industri personal watercraft berjalan dalam setahun seperti biaya produksi, gaji karyawan dan biaya perawatan dengan rincian pada tabel sebagai berikut.

Tabel 5.

Total Biaya Operasional

\begin{tabular}{|c|c|c|c|c|}
\hline No & Deskripsi & Unit & $\begin{array}{l}\text { Gaji Perbulan } \\
\text { (Rupiah) }\end{array}$ & $\begin{array}{c}\text { Gaji Total } \\
\text { pertahun (Rupiah) }\end{array}$ \\
\hline 1 & General Manager & 1 & $13.000 .000,0$ & $182.000 .000,0$ \\
\hline 2 & Sekretaris GM & 1 & $9.000 .000,0$ & $126.000 .000,0$ \\
\hline 3 & Manager PPIC & 1 & $9.000 .000,0$ & $126.000 .000,0$ \\
\hline 4 & Manajer Marketing & 1 & $9.000 .000,0$ & $126.000 .000,0$ \\
\hline 5 & Manager HRD & 1 & $9.000 .000,0$ & $126.000 .000,0$ \\
\hline 6 & Manager Produksi & 1 & $9.000 .000,0$ & $126.000 .000,0$ \\
\hline 7 & Mandor/ Kepala bagian & 1 & $9.040 .000,0$ & $126.560 .000,0$ \\
\hline 8 & Pegawai Laminasi & 4 & $6.000 .000,0$ & $336.000 .000,0$ \\
\hline 9 & Helper/Pembantu & 4 & $4.000 .000,0$ & $224.000 .000,0$ \\
\hline 10 & Mekanik \& Kelistrikan & 4 & $6.000 .000,0$ & $336.000 .000,0$ \\
\hline 11 & Proses Finishing & 4 & $6.000 .000,0$ & $336.000 .000,0$ \\
\hline 12 & Manager Administrasi dan Keuangan & 1 & $9.000 .000,0$ & $126.000 .000,0$ \\
\hline 13 & Staff $P P I C$ & 2 & $6.000 .000,0$ & $168.000 .000,0$ \\
\hline 14 & Staff Marketing & 2 & $6.000 .000,0$ & $168.000 .000,0$ \\
\hline 15 & Staff HRD & 2 & $6.000 .000,0$ & $168.000 .000,0$ \\
\hline 16 & Kepala Bagian QC dan Staff & 2 & $6.200 .000,0$ & $173.600 .000,0$ \\
\hline 17 & Staff Administrasi dan Keuangan & 2 & $6.000 .000,0$ & $168.000 .000,0$ \\
\hline 18 & Supir & 1 & $3.500 .000,0$ & $49.000 .000,0$ \\
\hline 19 & Office Boy & 2 & $3.500 .000,0$ & $98.000 .000,0$ \\
\hline 20 & Satpam & 1 & $4.000 .000,0$ & $56.000 .000,0$ \\
\hline \multicolumn{2}{|r|}{ Total } & 38 & $139.240 .000,00$ & Rp $3.345 .160 .000,00$ \\
\hline
\end{tabular}

Tabel 5 menunjukkan biaya operasional berupa gaji pegawai yang direncakan. Berdasarkan tabel di atas, dari total pekerja langsung, pekerja tidak langsung yang direncanakan industri personal watercraft, perhitungan bulan sejumlah 14 dengan pertimbangan gaji ke-13 dan bonus hari besar. Sehingga dibutuhkan total biaya pegawai setiap tahunya sebesar Rp. 3.345.160.000,00.

\section{F.Analisis Harga Pokok Produksi Industri Personal Watercraft}

Harga pokok produksi terdiri dari beberapa komponen antara lain, biaya bahan baku langsung, biaya tenaga kerja langsung, dan biaya overhead manufaktur [5]. Karena itu di bawah ini akan dibahas beberapa komponen dari harga pokok produksi yang dibutuhkan untuk pembuatan produk PWC.

Tabel 6.

Total harga Pokok Produksi 1 Unit PWC

\begin{tabular}{|l|l|lr|}
\hline No & \multicolumn{1}{|c|}{ Jenis Blaya } & \multicolumn{2}{c|}{ Nominal } \\
\hline 1 & Biaya Material & $R \varphi$ & 132.873 .150 \\
\hline 2 & Biaya tenaga kerja langsung & $R \varphi$ & 17.437 .404 \\
\hline 3 & Biaya Overhead & $R p$ & 16.092 \\
\hline Total Biaya produksi & $R p$ & 150.326 .646 \\
\hline
\end{tabular}

Tabel 6 menunjukkan total HPP untuk 1 unit personal watercraft. Total HPP adalah Rp 150.326.646.

\section{G.Analisis Penentuan Harga Penjualan Produk Personal Watercraft}

Pada sub-bab ini akan dibahas tentang harga penjualan yang diambil oleh perusahaan untuk menjual produk/barang/jasanya. Menurut (Handoko, 1997) untuk menghitung harga jual, salah satu pendekatan yang umum digunakan adalah metode mark-up pricing atau juga disebut sebagai cost-plus pricing [6]. Metode ini menambahkan beberapa persentase (mark-up) dari HPP atau total biaya dalam produksi produk/jasa yang ditawarkan tersebut.

- HPP = Rp. 150.326.646.

- Unsur Mark- up biaya umum dan administrasi seperti (biaya iklan, utilitas non-pabrik, serta gaji pegawai non-organik) $5 \%$ dari HPP

- Ekspektasi laba 34\% dari HPP

Mark - up pricing $=$ Rp. $150.326 .000+(34 \% \times \mathrm{Rp}$. 150.326.646)

Jadi harga jual produk produk PWC minimal adalah Rp. 210.457.304. Pemilihan 34\% sebagaimana yang dimaksud oleh (Suad \& Suwarsono, 2014) dalam bukunya, bahwa angka dari mark-up pricing harus bisa kompetitif dengan pesaing lainnya. Untuk analisis kompetitor akan dibahas setelah subbab ini, pertimbangan harga personal watercraft dibanding perusahaan lainya, membuat perusahaan mengambil mark-up pricing di angka $34 \%$.

\section{H. Analisis Target Produksi dan Pendapatan}

Target produksi yang diambil dari hasil peramalan data penjualan produk PWC Yahama Waverunner adalah 66\% dari keseluruhan. Untuk lebih detailnya berikut adalah tabel penjabaran target produksi sebagai berikut:

Tabel 7.

Target Produksi personal watercraft

\begin{tabular}{|l|r|r|r|r|r|}
\hline Hasil Peramalan PWC & \multicolumn{1}{|c|}{2017} & \multicolumn{1}{|c|}{2018} & \multicolumn{1}{c|}{2019} & \multicolumn{1}{c|}{2020} & \multicolumn{1}{c|}{2021} \\
\hline Jumlah Permintaan & 60 & 60 & 60 & 60 & 60 \\
\hline
\end{tabular}

Pada tabel 7 dijelaskan target produksi dalam satu tahun masing-masing produk dari tahun 2018-2023 adalah 60, 60, 60, 60, 60 unit. Perhitungan produksi pada tabel 7 didapatkan dengan pertimbangan-pertimbangan : Harga produk pwc yang dijual lebih murah daripada yang ada dipasaran dikarenakan produksi dalam negeri yang tidak terkena biaya pengiriman internasional dan pajak barang import, produk PWC yang dipasarkan mudah didapat dan memiliki kecepatan delivery 
yang lebih baik karena letak geografis, selain itu juga sudah mempertimbangkan faktor kualitas dan keunikan produk.

Tabel 8.

\begin{tabular}{cr}
\multicolumn{2}{c}{ Pendapatan Kotor Tiap Tahunya } \\
\hline \hline Tahun & Pendapatan (Rupiah) \\
\hline $\mathbf{2 0 1 8}$ & 12.086 .262 .335 \\
$\mathbf{2 0 1 9}$ & 12.690 .575 .452 \\
$\mathbf{2 0 2 0}$ & 13.325 .104 .225 \\
$\mathbf{2 0 2 1}$ & 13.991 .359 .436 \\
$\mathbf{2 0 2 2}$ & 14.690 .927 .408 \\
$\mathbf{2 0 2 3}$ & 15.425 .473 .778 \\
\hline \hline
\end{tabular}

Tabel 8 merupakan rencana pendapatan industri personal watercraft 2018-2023. Tabel tersebut merupakan hasil dari perkalian Tabel 8 target produksi dalam lima tahun dengan harga pokok produksi. Rencana pendapatan dengan terget produksi sebesar $100 \%$ bisa dilihat bahwa tren dari rencana pendapatan cukup positif dan relatif meningkat. Selain harganya yang kompetitif di pasaran, personal watercraft ini menjawab hampir banyak dari permasalahan dari ketersedian produk PWC yang lebih murah dan mudah didapat.

\section{Analisis Kelayakan Investasi}

Untuk menganalisis kelayakan pembangunan suatu perusahaan diperlukan analisis secara ekonomis, dalam hal ini metode yang digunakan adalah Payback period, Net Present Value, dan Internal Rate of Return. Perhitungan kelayakan investasi dilakukan berdasarkan biaya investasi, biaya produksi, biaya operasional, tax, dan pendapatan. Biaya investasi industri personal watercraft sebesar $\mathrm{Rp}$. 10.058.094.719 yang dibebankan 50\% dari pinjaman bank dan $50 \%$ dari dana pribadi. Untuk melakukan perhitungan kelayakan investasi, maka diperlukan rencana pendapatan seperti yang tertera pada lampiran tentang analisis kelayakan investasi, dari sana akan didapatkan arus kas per tahun yang selanjutnya akan dilakukan perhitungan payback period.

Tabel 9.

Kriteria Penilaian Industri Personal Watercraft

\begin{tabular}{lr}
\hline \hline \multicolumn{1}{c}{ Kriteria } & \multicolumn{1}{c}{ Nilai } \\
\hline Net Present Value & Rp. 1.136.894.723,30 \\
Payback Period & 9,67 tahun \\
IRR & $12,02 \%$ \\
\hline \hline
\end{tabular}

Dari Tabel 9 didapat nilai dari investasi dengan metode IRR, Payback period, dan Net Present Value (NPV) pada perhitungan tersebut didapatkan payback period terjadi pada tahun ke 9 bulan ke 8 . Pada tahun ke 9 bulan ke 8 terdapat net present value sebesar Rp. 1,136 milliar. Sedangkan nilai Internal rate of return sebesar 12,02\%. Untuk nilai IRR ini akan dibandingkan dengan minimum atractive rate of return (MARR), yang menurut (Husnan \& Suwarsono, 2014) [7] apabila IRR > MARR, maka ide usaha/bisnis tersebut layak secara finansial. MARR senilai $11 \%$ maka industri personal watercraft dinyatakan layak secara ekonomis.

\section{KESIMPULAN}

Berdasarkan analisis yang telah dilakukan serta sesuai dengan tujuan penulisan, dapat ditarik kesimpulan sebagai berikut:

1. Saat ini tidak adanya industri personal watercraft di Indonesia, namun terdapat beberapa distributor lokal yang mengimpor PWC merk terkenal ke Indonesia dengan perbandingan harga impor jauh lebih mahal dari harga asli. Maka dari itu pasar dari produk PWC di Indonesia dapat diketahui dari data-data penjualan yang di miliki oleh distributor-distributor PWC di Indonesia.

2. Untuk pembangunan industri personal watercraft diperlukan luas tanah sebesar $1.584 \mathrm{~m}^{2}$. Di dalamnya terdapat bangunan tertutup sebesar $844,5 \mathrm{~m}^{2}$. Proses pembuatan PWC terdiri dari proses persiapan dan laminasi, assembly, finishing serta function test. Diindikasikan produk dapat berbagai tujuan karena memenuhi persyaratan kelas BKI.

3. Biaya investasi yang diperlukan dalam pembuatan industri personal watercraft adalah sebesasar $\mathrm{Rp}$. 10,058 milliar dan payback period terjadi pada tahun ke 9 bulan ke 8, dengan nilai net present value sebesar Rp. 1,136 milliar, dengan nilai Internal Rate of Return sebesar 12,02\%, lebih besar dari suku bungan investasi yakni $11 \%$. Sehingga investasi ini dapat dikatakan layak.

\section{UCAPAN TERIMA KASIH}

Penulis mengucapkan terima kasih kepada Bapak Ir. Triwilaswandio Wuruk Pribadi M.Sc. selaku dosesn pembimbing studi, Bapak Ir. Wasis Dwi Aryawan, M.Sc., Ph.D. selaku Kepala Departemen Teknik Perkapalan ITS, beserta dosen dan karyawan di Departemen Teknik Perkapalan ITS yang telah membantu dan membimbing penelitian ini sampai terbitnya jurnal ini.

Penulis mengucapkan terima kasih kepada Ayah dan Ibu tercinta yang telah membesarkan penulis atas do'a, kasih sayang, dukungan, dan bimbingannya yang tidak pernah berhenti.

\section{DAFTAR PUSTAKA}

\footnotetext{
M. F. Company, Evaluation Guide for Selecting the Best FRP Composite Process for Your Projec. 2011.

A. B. of Shipping, Guide for Building and Classing High Speed Craft. Houston: American Bureau of Shipping, 2011.

Y. WaveRunner, "Daftar Harga Yamaha WaveRunner 2017," Jakarta, 2017.

Sumayang, Forecasting. Jakarta: Gramedia, 2003.

Riyanto, Analisis Kelayakan Investasi Bisnis. Yogyakarta: Jalasutra, 1998.

T. H. Handoko, Studi Kelayakan Proyek. Yogyakarta: Bintang Pusaka, 1997.

S. Husnan, S., \& Muhammad, Studi Kelayakan Proyek Bisnis. Yogyakarta: Sekolah Tinggi Ilmu Manajemen YKPN, 2014.
} 